\title{
DIVERSITY OF EXINE'S ORNAMENTAL CHARACTER STUDIES IN FERN AND FLOWERING PLANT
}

\author{
Septi Kurniama Sari, Nur Azizah, Rizqy Amalia Ananda, Kristin Kusuma Ratih \\ Biology Departement, Faculty of Mathematics and Natural sciences \\ State University of Malang, Malang, Indonesia \\ tza_rosemary@yahoo.com; azizah2392@ahoo.com; ananda.indica@gmail.com; \\ kristinkusumaratih@yahoo.com
}

\begin{abstract}
Pollen or pollen wall consists of two layers, namely exine and intine. Exine (outer layer) composed of sporopolenin, and intine (inner layer) composed of cellulose. Pollen wall structure, especially the Exine, is one of the characters used for identification. The shape and type of pollen or spores of each specific plant species. Exine's ornamentation have variations in form and structure. That like are thorns, scratches, basins and other types of ornamentation. Pollen and spore sampling is done randomly in some plants that are supposed to represent members berspora ferns (Asplenium nidus, Platycerium bifurcatum, and Microsorum diversifolium) and pollen of flowering plants (Ipomea sp., Tridax procumben. And flowers Crinum asiaticum). Spores of Asplenium nidus to have a corrugate apertura monocalpalae with ornaments. Platycerium bifurcatum spores aperture shape gemenete dicolpale with ornaments, while the spores Microsorum diversifolium has the form apertura psilatum dicolpalae with ornaments. Polen has Tridax procumben apertura echinatus peripole with ornaments, Ipomea sp. has the form apertura saculate peripole with ornaments, while the Crinum asiaticum has the form apertura clevate peripole with ornaments. The diversity of spore of plant species in nature have affect the diversity of forms of ornamentation owned.
\end{abstract}

Key words: Diversity, exine, ornament's type, spores and pollen.

\section{INTRODUCTION}

Earth has a high biodiversity. Not only in Indonesia, the number of plant species are many and varied. Research relating to the taxonomy has been done began from organ morphology and physiology of plants until the anatomy. One way to determine the taxonomic of plant was by observing morphological features of pollen or spores.

Pollen and spores can be used to identify the plant because there are pollen exine structure and ornamentation having a distinctive and can be preserved. It contains sporopolenin that resistant to organic materials and asetolisis. Pollen and spores of plants quite its various forms. The diversity of shapes, sizes, and types in the pollen wall carvings is very spacious and has a value in the identification of plants and even pollen or spores that have become fossilized. Pollen and spores have specific characters consisting of the shape, aperture, sclupture / wall ornamentation, symmetry and size. According to Blackmore (In: Hesse \& Ehrendorfer, 1990) differences in pollen morphological characters can be used to identify the type, construction or interpretation of phylogenetic classification.

Pollen is yellow granules produced by flowering plants (Spermatophyta). Plants from Spermatophyta group, in flowering season will produce pollen as the male sex cells. It's also called flowering plants. Angiosperms is characterized by flowers composed of male flowers and female flowers in the flower stalk. Pollen grains in stamens surround the female flowers around the sides. Angiosperm also known as a closed seed plants, which shows the devel-

ISSN 2413-0877 (C) 2015 The Authors.

Published by KnowledgeE Publishing Services This is an open access article under the CC BY-NC-ND license (http://creativecommons.org/licenses/by-nc-nd/4.0)

Selection and Peer-review under responsibility of the 3rd ICBS-2013

Doi http://dx.doi.org/10.18502/kls.v2i1.221 
opment of the fruit of the female flower parts.

Spores produced by the plants from group Pterophyta, Bryophyta, and Sebaian Thallophya. Pterophyta classes (ferns), there are produced two types of spores called heterospore. Male spores has a smaller size than females spores. There is another group of Thallophyta that produce same size of spores, so it can not distinguish between males and females, such spores called Isospora that generally have a very small size. Pterophyta better known as ferns.

Polen character that important in the study of pollen there was unit pollen, pollen polarity, pollen symmetry, pollen shape, type and aperture type and exine ornamentation (Erdtman, 1966). Erdtman (1966), grouping form of pollen based on the comparison between the polar axis $(P)$ with its axis equatorial $(E)$. Polar axis is the axis of rotation and the axis of the equatorial location on the aperture.Based on its function, pollen aperture serves as the discharge of the cell fluid in the process of fertilization. Thanikaimoni (in Blackmore and Ferguson, 1986), explains morphologically that the aperture is eksin open and thin areas, initin usually thickened.Outer pollen wall (eksin), consists of two layers the outer layer called ekteksin and the inner layer is called endeksin. In the outer layer of the eksin there garnish (ornamentation / sclupture) which essential for pollen description.

\section{MATERIALS AND METHODS}

This research was conducted at the Laboratory of Plant Microtechnic, Department of Biology, Faculty of Science, University of Malang. The research was conducted on 22 March to 28 March 2013. The tools and materials used are sporofil ferns, anthera, pollen, spores,

glacial acetic acid, acetic anhydride, concentrated sulfuric acid, distilled water, sodium cholrat, $\mathrm{HCl}$, glycerine jelly, safranin, alcohol, xylol, canada balsam, microscope.

Samples were taken at random, represented by the ferns is Asplenium nidus, Platycerium bifurcatum, and Microsorum diversifolium while pollen of flowering plants is Ipomea sp., Tridax procumben and Crinum asiaticum. The method used is the asetolisis method with through specimen collection process from nature, using centrifuges centrifuging, heating, dyeing, bleaching and finishing stages. The observations were made using a microscope enlargement 1000x.

\section{RESULT AND DISCUSSION}

Pollen grain has a specific character consisting of the shape, aperture, sclupture / wall ornamentation, symmetry and size. According to Blackmore (In: Hesse \& Ehrendorfer, 1990) differences in pollen morphological characters can be used to identify the type, construction or interpretation of phylogenetic classification. Pollen and spore sampling is done randomly in some plants that are supposed to represent members ferns spora (Asplenium nidus, Platycerium bifurcatum, and Microsorum diversifolium) and pollen of flowering plants (Ipomea sp., Tridax procumben., and Crinum asiaticum flowers).

Asplenium nidus spores contained ornament on its edges. Asplenium nidus looks like a half circle with a curved line, looks like a crescent moon. When its viewed from face downward position, its have spherical spores rather oval face, a nearly spherical shape. Ornament on spore A.nidus almost bumpy and irregular, tapered at the outer side and dull on the 
inside. Spores of $A$. nidus as shown in Figure 1. Ornament looked around the spores. On spore Microsorum diversifolium shape similar to the Asplenium nidus spores, only the spores Microsorum diversifolium half very convex, the other half is not too sunken in, making it seem closer to a half circle. Moreover spores Microsorum diversifolium has no ornament (figure 2).

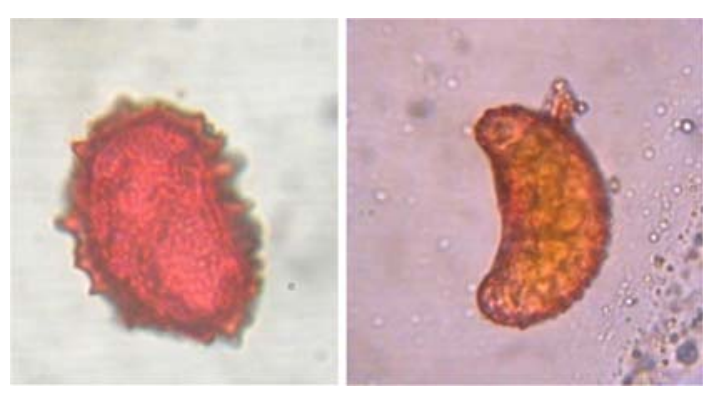

Figures 1 and 2. Spores of Asplenium nidus has monocalpale aperture shape with corrugate ornament (left) form and Microsorum diversifolium spora has the dicolpalae aperture with psilatum ornament (right)

Spores that look different from the others is Platycerium bifurcatum spores, the spores did not resemble the form of a half circle but more similar to soybean seeds with hilum thick. Judging from the face downward position looks like the back of rats. Its has similar small bumps on several sides.

Figure 3. Platyceriumbifurcatum spores have dicolpalae aperture shape with Gemenete ornament

Observations on pollen Tridax procumbent has a round shape with spines with surface ornament such as a round hole on most surfaces. Its similar to pollen also owned by Krangkong, but its has bigger pollen. Ornament in Ipomoea sp. also like thorns but not acute but blunt, has subtle bulge look like a little long.
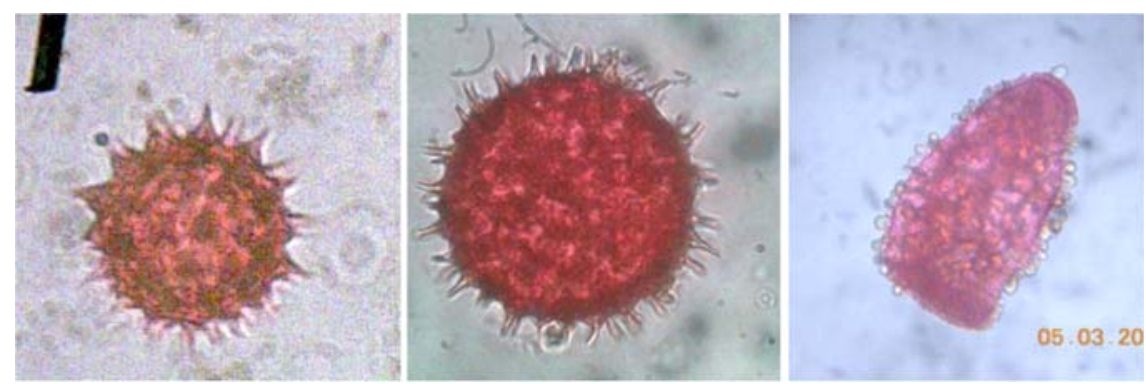

Figure 4, 5 and 6. Trdax procumbent spores have periporale aperture shape with Echinatus ornament (left), Ipomoea sp. spores having aperture shape periporale with Saculate ornament (middle), and Crinum asiaticum spores has periporale aperture with Clevate ornament (right) 
Lily or Crinum asiaticum has a spora with different shape, it is shaped like a hat (hat the farmer) but on the flat part of the hat on this pollen convex. Lily's polen size large enough compared to even most other spores and have been observed. If viewed from a prostrate position was shaped oval with both ends slightly flat. Ornament owned small dots shaped like tiny bubbles that envelop pollen. The observations we have made of 6 samples found 3 types namely monocalpalae aperture, periporalae, dicolpalae.

Platycerium bifurcatum,Asplenium nidus and Microsorum diversifolium spores follow the basic form of pollen, spores observations based on the results of the third fern has an oblate shape with a ratio of $4 / 8$. Based on the comparison between the polar axis with the axis equatorial, pollen of Crinum asiaticum have oblate shape with a ratio of $4 / 8$. While pollen on Tridax procumben and Ipomoea sp. flowers have the same shape with the oblate spheroidal 8/8. From comparison study can be result that diversity of plant spore species in natural influence possessed forms of ornamentation.

\section{REFERENCES}

Blackmore, S. and S.H. Barnes. 1990. Comparative Studies of Mature and Developing Pollen Grains. In: Vlaugher, D. (editior). Scanning Electron Microscopy in Taxonomy and Fuction Morphology, Sytematic Assotiation Special Volume No. 41. pp 1-21. Oxford, Clarendon Press

Erdtman, G. 1966. Pollen Morphology and Plant Taxonomy Angiosperm, New York, Hafner Publishing Company

Nugroho, Hartanto. 2006. Struktur dan Perkembangan Tumbuhan. Depok : Penebar Swadaya.

Suntoro, H. 1983. Metode Pewarnaan (Histologi dan Histokimia). Yogyakarta : Fakultas Biologi UGM.

Rahmawati, A. 2001. Morfologi Ultrastruktur Spora Lycopodium di jawa. Biota Vol. VI (I): 1728, Februari. UGM. 